\title{
Suture complications in a teaching institution among patients undergoing uterosacral ligament suspension with permanent braided suture
}

\author{
Tajnoos Yazdany • Sallis Yip • Narender N. Bhatia • \\ John N. Nguyen
}

Received: 20 November 2009 / Accepted: 10 January 2010 / Published online: 26 February 2010

(C) The Author(s) 2010. This article is published with open access at Springerlink.com

\begin{abstract}
Introduction and hypothesis Our study aimed to identify the rate of suture complications over a 5 -year period using braided permanent suture for uterosacral ligament suspension (USLS) surgery.

Methods We reviewed the medical records of patients who underwent vaginal uterosacral ligament suspensions using braided polyester suture. Outcome measures included rate and timing of suture complications, patient symptoms postoperatively, efficacy of treatment modalities and surgical success.

Results Eighty-three patients had undergone USLS with braided, polyester suture over the study period that met inclusion criteria. Thirty-seven patients (44.6\%) had suturerelated complications post-operatively with a mean followup of 10.4 months. When only silver nitrate was applied, $16.7 \%$ improved, and when the suture was cut in clinic, $77.8 \%$ resolved.
\end{abstract}

T. Yazdany $(\bowtie) \cdot$ N. N. Bhatia

Division of Female Pelvic Medicine and Reconstructive Surgery,

Harbor UCLA Medical Center,

1000 W. Carson Street, Bldg D3 Box 489,

Torrance, CA 90509, USA

e-mail: tyazdany@obgyn.humc.edu

S. Yip

Obstetrics \& Gynecology, Harbor UCLA Medical Center,

Torrance, CA, USA

J. N. Nguyen

Division of Female Pelvic Medicine and Reconstructive Surgery,

Kaiser Permanente Downey Medical Center,

Downey, CA, USA

N. N. Bhatia $\cdot$ J. N. Nguyen

David Geffen School of Medicine at UCLA,

Los Angeles, CA, USA
Conclusions Permanent polyester braided suture for suspension of vaginal vault may lead to an unacceptably high suture erosion rate, cutting the suture in clinic results in the highest resolution.

Keywords Polyester suture · Suture complications · Uterosacral ligament suspension · Vaginal vault prolapse . Vault suspension

Abbreviations
USLS uterosacral ligament suspension

\section{Introduction}

Uterine and vaginal vault prolapse affects a large percentage of our aging population. Apical prolapse remains an important surgical challenge, with a significant percentage of patients requiring re-operation within a few years. Multiple surgical approaches, both vaginal and abdominal, have been used to treat this bothersome condition. More recently, mesh augmentation using pre-made kits have gained popularity for their ease and rapidity of placement. However, these techniques have not undergone rigorous study for short- and long-term complications. One popular approach to apical surgery is the uterosacral ligament suspension (USLS). It requires an intimate understanding of female pelvic anatomy and has been investigated by both retrospective and randomized studies. Researchers have found a $2-13 \%$ rate of recurrent vault prolapse. However, as with many surgical procedures, no uniform or standardized surgical approach has been established that improves outcome and reduces complications. No consensus exists on the types of sutures to use, how closely the sutures 
should be placed to the vaginal vault, or how many sutures should be placed on each side. Surgeons have reported using monofilament, delayed absorbable and permanent polyester sutures. Many believe that permanent suture will result in a more durable repair; however, no systematic comparisons have been made with other suture types. The aim of this study was to report the suture related complications in patients undergoing uterosacral ligament suspension with permanent braided polyester suture. Our secondary aim was to examine the rate of prolapse recurrence.

\section{Materials and methods}

We performed a retrospective cohort study of patients who underwent vaginal uterosacral ligament suspensions at Harbor UCLA Medical Center between March 2003 and March 2008. Institutional review board approval was obtained. All patients who had a vaginal approach were eligible for the study. Patients were excluded if they had abdominal or laparoscopic suspensions or had less than a 4-week follow-up. We gathered demographic data including age, parity, medical comorbidities, previous pelvic and urogynecologic procedures, and use of vaginal or oral estrogens from patient medical records. Intra-operative and post-operative complications, follow-up treatment, and post-operative prolapse recurrence and incontinence were abstracted from patient charts.

All patients underwent pre-operative pelvic examination. Pelvic organ prolapse was quantified using the BadenWalker halfway system from 2003 to 2006 and the pelvic organ prolapse quantification system [1] from 2006 to 2008. Each subject underwent urodynamic assessment that included retrograde multichannel urethrocystometry, passive urethral pressure profilometry, cough and valsalva leak point pressures, simple uroflowmetry, post-void residual volume determination, and cystourethroscopy. Leak point pressures were evaluated both with and without prolapse reduced with two fox swabs to identify patients with occult incontinence.

Fellows and residents operated on patients in the Division of Pelvic Medicine and Reconstructive Surgery under the supervision of the two senior faculty members at our institution. Patients were given pre-operative antibiotics and sequential compression stockings for deep vein thrombosis prophylaxis. Once the hysterectomy with or without oopherectomy was performed, a moist laparotomy sponge was placed into the posterior cul-de-sac. Two BreiskyNavratil retractors were placed to protect the pelvic sidewall and help with visualization and palpation of the uterosacral ligament. The uterosacral ligament was identified and grasped $1 \mathrm{~cm}$ medial and posterior to the ischial spine with an allis clamp. A No. 0 permanent braided polyester suture (Ticron,
Tyco, Norwalk, CT, USA) was placed laterally to medially at this location and a second suture placed $1 \mathrm{~cm}$ cephalad to the first. This was repeated on the contralateral side. Once the sutures were secured, indigo carmine was injected intravascularly and cystoscopy performed. We placed lateral and medial tension on the suspension sutures while confirming bilateral ureteral efflux. Additional procedures were performed to repair defects in the anterior wall in a site-specific manner without the use of mesh. Patients who were identified with urodynamic stress or mixed incontinence underwent a sling procedure with Advantage* or Obtryx* (Boston Scientific Natwick, MA, USA) device using standardized techniques. After these procedures were performed, the USL sutures were attached sequentially to the anterior and posterior vaginal cuff while avoiding vaginal epithelium. Care was taken to stay 1 to $1.5 \mathrm{~cm}$ away from the outside margin of the cuff. The medial USL sutures were then tied before the lateral ones. Incontinence procedures and posterior compartment repairs were performed after repair of the anterior compartment, apical suspension procedure, and cuff closure, when appropriate. Irrigation was performed and the cuff was closed with interrupted No. 0 delayed absorbable sutures.

Patients were evaluated at 1 week, 6 weeks, 3 months, and 1 year. At each post-operative visit, patients were asked about incontinence, discharge, or bleeding. Suture erosion was defined as suture visible at the cuff greater than 6 weeks after surgery. Patients with suture-related complications underwent one of four possible treatments; observation, silver nitrate application, suture removal in clinic, or suture removal in the operating room. The type of treatment was based on clinician preference and severity of symptoms. Vaginal estrogen was given at the discretion of the physician. If outpatient interventions failed, the patient was ultimately taken to the operating room for suture removal and partial colpocleisis of the area of suture exposure.

Outcome measures included rate and timing of suture complications, patient symptoms, efficacy of treatment modalities, and surgical success. Recurrent prolapse was defined as Stage II or greater prolapse in any one compartment. We used basic descriptive statistics and chisquare analysis for evaluation of discrete variables. Data was analyzed using SigmatStat 3.5 (SigmaStat, Ashburn, VA, USA)

\section{Results}

Ninety-three patients underwent uterosacral ligament suspension with permanent braided, polyester suture over the 5 -year study period. Four patients with abdominal USLS, three with laparoscopic USLS, and three patients with less than 4 weeks follow-up were excluded. The clinical and demographic characteristics of the 83 patients included in 
the analysis are presented in Table 1 . The mean $( \pm$ standard deviation) age at surgery and mean parity of the 83 patients included in the analysis was $54.1 \pm 9.9$ (range 37-76) and 4 (range of $0-16)$, respectively. Approximately 56 (67.5\%) patients were post-menopausal and $71.0 \%$ of our patient population was Hispanic. Eighty-one patients $(97.6 \%)$ had a concurrent hysterectomy and 53 patients $(63.9 \%)$ had anterior colporrhaphies. Mean blood loss was $301.5 \mathrm{cc}$ $( \pm 199)$. Median length of hospitalization was one day (mean 1.52, range $1-5, \mathrm{SD}=0.088$ ).

Peri-operative complications occurred in 19 patients (22.9\%; Table 2). Surgical complications included blood loss requiring transfusion (two patients), fever [2], cuff abscess [1], and ureteral injury requiring stent placement [3]. Six (7.2\%) additional patients had ureteral kinking identified during intra-operative cystoscopy and the offending suture was removed and replaced without further event. Post-operatively, two patients complained of buttock pain and three complained of leg numbness.

Two patients had new and ten patients had recurrent prolapse $(14.5 \%)$ noted at their post-operative visit and none underwent repeat surgery at our institution. Mean follow-up was 10.4 months (range 1.13-62). The two patients with new prolapse had anterior vaginal wall prolapse and recurrent prolapse occurred in the anterior compartment (eight, 9.6\%), posterior compartment (three, 3.6\%), and apex in one patient $(1.2 \%)$. Forty patients $(48.2 \%)$ complained of stress incontinence symptoms pre-operatively, six of which had negative urodynamics and two who declined surgery. Patients who had concomitant slings with their prolapse repair had symptomatic improvement in their symptoms in $93.8 \%$ (30/32) of cases.

Thirty-seven patients (44.6\%) had suture-related complications noted at their 6-8-week visit. Thirty of the 37

Table 1 Summary data

\begin{tabular}{|c|c|}
\hline Summary data & $N$ \\
\hline Cases & 93 \\
\hline Excluded & 10 \\
\hline Analyzed & 83 \\
\hline Age $( \pm$ SD $)$ & $54( \pm 9.9)$ \\
\hline Mean follow-up (range) & 10.4 (1.1, 62 months $)$ \\
\hline Patients with prior surgery & $2(2.4 \%)$ \\
\hline Patient with prior hysterectomy & $2(2.4 \%)$ \\
\hline Post-menopausal (\%) & $56(67.5 \%)$ \\
\hline \multicolumn{2}{|l|}{ Ethnicity } \\
\hline Hispanic & $59(71.0 \%)$ \\
\hline Black & $10(12.0 \%)$ \\
\hline White & $7(8.4 \%)$ \\
\hline Asian & $6(7.2 \%)$ \\
\hline Other & $1(1.2 \%)$ \\
\hline
\end{tabular}

patients $(36.1 \%)$ had suture exposure and seven patients $(8.4 \%)$ were found to have only granulation tissue at the cuff. Patients with suture-related complications presented for routine follow-up with no symptoms (51.3\%), vaginal bleeding (40.5\%), and discharge (8.2\%). In twenty-four patients, suture was visible by their 3-month visit (range $2.53-9.8 ; 64.9 \%$ ).

At the time of this audit, $48.6 \%$ (18/37) had resolution of their suture-related complications and 19 patients did not. Of these 19 patients, 11 were lost to follow-up. Seven of the 11 patients who were lost to follow-up were asymptomatic $(63.6 \%)$ at the time of their last visit. Seven of the total 37 patients had only granulation tissue noted, with three of these patients showing resolution $(3 / 7=42 \%)$ after silver nitrate was applied, the other four did not return to clinic. Of the 30 patients with suture visible at the cuff, patients were either managed conservatively with observation, silver nitrate only, or silver nitrate and suture removal in clinic. Only one of six (16.7\%) patients with suture visible at the vaginal cuff improved when only silver nitrate was applied and $77.8 \%$ resolved (7/9) when the suture was cut in clinic. Only 6/14 (42.8\%) patients resolved when nothing was done $(p=0.36)$. One additional patient had suture removed in the OR with resolution of her symptoms. Suture on average was cut 4.3 months after surgery ( $\mathrm{SD} \pm 113$ days). One patient had recurrent prolapse that had suture cut $1 / 10$ $(10 \%)$. These patients were followed on average 5.58 months $( \pm 20.5)$ after the suture was cut.

Univariate analysis showed no increased risk of hypertension or diabetes in the group with suture complications. Also, menopausal status and age did not significantly impact suture complications and there was no statistically significant difference between patients with and without suture erosion ( $p=0.2$ and $p=0.85$, respectively). There was no difference in patients who did and did not receive postoperative estrogen $(p=0.89)$. Length of hospitalization did not differ in patients with (17 1 day, 19 greater than 1 day) and without suture complications (32 1 day, 15 greater than 1 day; $p=0.29$ ).

Type of concomitant procedure was not shown to impact development of suture complications. Patients undergoing posterior repairs $(p=0.89)$, anterior repairs $(p=0.93)$, slings $(p=0.46)$, or patients undergoing more than three procedures at one time $(p=0.36)$, did not show a difference in rate of suture complication (Table 3).

\section{Discussion}

Few studies have evaluated the most effective and safe suture for uterosacral ligament vault suspension (Table 4). Although performed for over 50 years, the technique has not been refined with robust comparative studies and most 
Table 2 Pre-operative complications and outcomes

\begin{tabular}{lllr}
\hline Complication & $N(\%)$ & Type & $N(\%)$ \\
\hline Suture complications & \multirow{2}{*}{37 patients $(44.6 \%)$} & Visible suture at cuff & $30(36.1 \%)$ \\
& & Granulation tissue only & $7(8.4 \%)$ \\
Post-operative prolapse & \multirow{2}{*}{12 patients (14.5\%) } & Anterior compartment & $8(9.6 \%)$ \\
& & Posterior compartment & $3(3.6 \%)$ \\
& & Apical & $1(1.2 \%)$ \\
Other peri-operative & \multirow{2}{*}{19 patients $(22.9 \%)$} & Cuff abscess & 1 \\
complications & & Transfusion & $2(2.4 \%)$ \\
& & Fever & $2(2.4 \%)$ \\
& & Buttock pain & $2(2.4 \%)$ \\
& Leg numbness & $3(3.6 \%)$ \\
& Ureteral kinking requiring stents & $3(3.6 \%)$ \\
& Ureteral kinking identified & $6(7.2 \%)$ \\
& & intra-op with resolution &
\end{tabular}

surgeons use clinical experience to guide their technique. In our study, there were a significant percentage of patients who developed either suture exposure or cuff granulation tissue post-operatively $(44.6 \%)$ while using permanent braided suture. Two previous studies have evaluated the rate of suture complications in patients undergoing vaginal surgery with similarly high rates of erosion. Toglia [2] found that patients undergoing sacrospinous ligament suspension with the same suture had a $36 \%$ rate of suture complications. Seventy percent of symptomatic patients required suture removal and $74 \%$ presented with vaginal bleeding. Our patients also presented with vaginal bleeding and discharge and the most effective treatment ultimately was complete suture removal.

Luck et al. [3] also found a high rate of suture complications $(31.3 \%)$ when using $2-0$ permanent braided suture in posterior vaginal wall repairs, while only $9 \%$ had suture complications when using absorbable suture. In addition, patients who had sphincteroplasties at the time of surgery with permanent suture were at additional risk for wound breakdown and suture complications. They found that wound disruptions occurred earlier with absorbable suture (median 20 days) as compared to permanent suture

Table 3 Concomitant procedures

\begin{tabular}{llr}
\hline Procedure & $N$ & Percent \\
\hline TVH & 81 & 97.5 \\
Anterior & 53 & 63.9 \\
$\quad$ With graft & 7 & 8.4 \\
Posterior & 45 & 54.2 \\
Anterior and posterior & 27 & 32.5 \\
Sling & 31 & 37.3 \\
BSO/USO & 12 & 14.5 \\
\hline
\end{tabular}

(median 53 days). Our findings, in addition to these published reports, add substantial evidence that the use of permanent braided suture at the suture line in vaginal procedures leads to bothersome symptoms and a high suture complication rate. Our paper reports suture complications in patients undergoing USLS procedures; however, as evidenced by these publications, permanent suture can cause problems in other types of vaginal procedures as well.

Other authors have reported outcomes from USLS procedures and type of suture used for these procedures varies widely. However, few have reported specifically on suture complications. Surgeons have used delayed absorbable [4-8], permanent monofilament [9] and permanent braided suture [10] with similar rate of recurrent prolapse. Aronson [11] was the only author who used braided suture and switched from $1-0$ polyglyactic acid to monofilament polydiaxanone during the study, however did not indicate a reason. This was presumably done for suture complications.

The reasons for suture complications are manifold. As the vaginal cuff is usually poorly vascularized postsurgically in post-menopausal women, there is a high risk of infection and healing problems. Foreign tissue reaction and chronic infection may lead to suture exposure and granulation tissue. Also, the cuff is often denuded of its peritoneum during hysterectomy and entrance into the pelvic cavity, which may impact wound healing. One option is to create clean margins by excising the cuff, prior to placing the sutures. Every effort should be taken by the surgeon to place the suture away from the cuff when passing through the posterior and anterior vaginal cuff. Ticron* is known for its tensile strength, but may have increased reactivity compared to monofilament suture such as polypropolene. It is likely that braided permanent suture inherently results in more suture complications in vaginal procedures, as compared to monofilament sutures. Some 
Table 4 Overview of uterosacral ligament vaginal vault suspension studies

\begin{tabular}{|c|c|c|c|c|c|}
\hline Author & Type of suture & Suture placement & Complications & Cuff Closure/Cystoscopy & Success Rate \\
\hline $\begin{array}{l}\text { Amunsden } \\
\text { et al. [7] }\end{array}$ & $\begin{array}{l}1 \text { polyglactin or } 0 \\
\text { polygylconate }\end{array}$ & $\begin{array}{l}1 \text { st —at level of ischial spine; } \\
2 \text { nd-more cephalad } \\
\text { then first }\end{array}$ & 1 transfusion & $\begin{array}{l}\text { Not commented. } \\
\text { Cystoscopy-before } \\
\text { tying sutures }\end{array}$ & $\begin{array}{l}\text { 27/33 (82\%) patient } \\
\text { satisfaction; } 94 \% \\
\text { objective cure }\end{array}$ \\
\hline $\begin{array}{l}\text { Aronson } \\
\text { et al. [11] }\end{array}$ & $\begin{array}{l}\text { 1-0 braided polyglyactic } \\
\text { acid, switched to } 1-0 \\
\text { monofilament poly- } \\
\text { diaxanone; } 3 \text { sutures } \\
\text { bilaterally }\end{array}$ & $\begin{array}{l}\text { Suture placed "deep" } \\
\text { dorsally and posterioraly in } \\
\text { the pelvis, through } \\
\text { pararectal portion of } \\
\text { ligament }\end{array}$ & $\begin{array}{l}24(5.9 \%) \text { blood } \\
\text { transfusions; } 2 \text { partial } \\
\text { SBO; } 1 \text { vaginal cuff } \\
\text { abscess; } 1 \text { patient had } \\
\text { ureteral injury }\end{array}$ & $\begin{array}{l}\text { Not mentioned timing of } \\
\text { cystoscopy or closure } \\
\text { style }\end{array}$ & Not mentioned \\
\hline $\begin{array}{l}\text { Barber } \\
\text { et al. [6] }\end{array}$ & $\begin{array}{l}\text { Monofilament and } 1-0 \\
\text { delayed absorbable } \\
\text { monofilament; } 2 \\
\text { sutures bilaterally }\end{array}$ & $\begin{array}{l}\text { Sutures are placed at the } \\
\text { level of ischial spine and } \\
1 \mathrm{~cm} \text { above }\end{array}$ & $\begin{array}{l}5 / 46(11 \%) \text { ureteral } \\
\text { injury }\end{array}$ & $\begin{array}{l}\text { Interrupted delayed } \\
\text { absorbable; Cystoscopy } \\
\text { after tying suture, but } \\
\text { before attaching to cuff }\end{array}$ & $90 \%$ objective \\
\hline Jenkins [4] & $\begin{array}{l}\text { 1-0 delayed absorbable } \\
\text { or monofilament; } 2 \\
\text { sutures bilaterally }\end{array}$ & $\begin{array}{l}\text { Placed into the medial/ } \\
\text { posterior/dorsal aspect of } \\
\text { the USL; 2nd suture placed } \\
\text { lateral to the first }\end{array}$ & $\begin{array}{l}3 / 50(6 \%) \text { suture } \\
\text { erosion }\end{array}$ & $\begin{array}{l}\text { Closed with delayed } \\
\text { absorbable suture; } \\
\text { Cystoscopy not } \\
\text { performed }\end{array}$ & $\begin{array}{l}\text { 48/50 }(96 \%) . \text { Failures } \\
\text { were asymptomatic } \\
\text { cystoceles }\end{array}$ \\
\hline $\begin{array}{l}\text { Karram } \\
\text { et al. [5] }\end{array}$ & $\begin{array}{l}0 \text { polypropylene; } 2-4 \\
\text { bilaterally delayed } \\
\text { absorbable to suspend } \\
\text { cuff }\end{array}$ & $\begin{array}{l}\text { USL palpated posterior and } \\
\text { medial to ischial spine and } \\
\text { placed above spine with } \\
\text { polypropelene and delayed } \\
\text { absorbable to suspend cuff }\end{array}$ & $\begin{array}{l}5 / 168 \text { ureteral injury } \\
(2.4 \%) ; 1 \text { small bowel } \\
\text { injury; } 1 \text { pelvic } \\
\text { abscess }\end{array}$ & $\begin{array}{l}\text { Not discussed. } \\
\text { Cystoscopy performed; } \\
\text { uncertain timing }\end{array}$ & $\begin{array}{l}\text { Patient satisfaction } \\
150 / 168(89 \%)\end{array}$ \\
\hline $\begin{array}{l}\text { Schull } \\
\text { et al. [10] }\end{array}$ & $\begin{array}{l}\text { Non-absorbable braided; } \\
3 \text { sutures bilaterally }\end{array}$ & $\begin{array}{l}\text { USL identified posterior and } \\
\text { medial to ischial spines at } 4 \\
\text { and } 8 \text { o' clock. Needles } \\
\text { passed lateral to medial }\end{array}$ & $\begin{array}{l}1 \% \text { transfusion, } 1 \% \\
\text { ureteral injury } / \text { kinking } \\
\text { rate, and } 0.3 \% \text { post- } \\
\text { operative death rate }\end{array}$ & $\begin{array}{l}\text { Continuous delayed } \\
\text { absorbable; cystoscopy- } \\
\text { before and after tying } \\
\text { suspensory sutures }\end{array}$ & $\begin{array}{l}251 / 289(87 \%) \\
\text { objective }\end{array}$ \\
\hline $\begin{array}{l}\text { Silva } \\
\text { et al. [8] }\end{array}$ & Same as Karram & Same as Karram & $\begin{array}{l}15.3 \% \text { with surgical } \\
\text { failure; no ureteral } \\
\text { injuries }\end{array}$ & $\begin{array}{l}\text { Not discussed; cystoscopy } \\
\text { performed; uncertain } \\
\text { timing }\end{array}$ & $84.7 \%$ objective \\
\hline $\begin{array}{l}\text { Wheeler } \\
\text { et al. [9] }\end{array}$ & $\begin{array}{l}\text { Monofilament } \\
\text { polypropolene; } 1 \text { suture } \\
\text { bilaterally }\end{array}$ & $\begin{array}{l}\text { Placed through the } \\
\text { peritoneum and adjacent to } \\
\text { the ligament } 1 \mathrm{~cm} \text { cephalad } \\
\text { and at the same posterior } \\
\text { level as the ischial spine }\end{array}$ & No ureteral injuries & $\begin{array}{l}\text { Continuous running; } \\
\text { cystoscopy after cuff } \\
\text { closure }\end{array}$ & $\begin{array}{l}\text { Patient satisfaction } \\
88.9 \%\end{array}$ \\
\hline
\end{tabular}

surgeons have even used polyglactin 910 suture with good results [2], claiming that scarring takes place that keeps the vault suspended as the suture breaks down [12]. Wheeler [9] chooses monofilament polypropylene sutures and places only one suture on each side and claims that this results in less devascularization at the vaginal cuff. After reviewing our own results, we have stopped using Ticron* suture and now all surgeons use polytrimethylene carbonate (Coviden synecture, Norwalk Connecticut) for vault suspension with good preliminary results.

There was also a significant risk of ureteral entrapment when the uterosacral ligament was suspended to the vaginal vault, as seen with previous studies $[6,11]$. Six patients required release of the suture intra-operatively with no sequela and three patients required stent placement. No patients needed ureteral re-implantation or repair. Based on these findings, we have modified our technique, placing a single throw securing the uterosacral ligament prior to cystoscopy. We believe that simply placing tension on the sutures during cystoscopy may not completely occlude an entrapped ureter in some cases.
The strengths of this study included the large number of patients with suture complications, allowing a glimpse into the natural history of suture erosion and cuff complications with different treatment approaches. Visualized suture or granulation suture may resolve if seen immediately postoperatively, however those presenting greater than 3 months after surgery may require intervention and suture removal. A few patients were followed for almost 3 or 4 years, and their suture complications did not resolve without treatment. Physicians are often uncertain of the natural course of suture exposure. As suture exposures likely will not resolve with time, as evidenced by the majority of our patients needing suture removal, it is recommended to remove suture at the time of visualization. Chronic infection and granulation tissue formation will result in continued problems with bleeding and discomfort.

The weakness of this study was the retrospective design and the inconsistent patient follow-up. Since level of physician experience differed at the post-operative visit, recurrent vault prolapse may have been underestimated. It was also impossible to know why physicians chose a 
certain intervention, and severity of findings or patient symptoms may have affected success of their intervention. A larger study size might have been able to identify differences between study groups in terms of age, blood loss, diabetes, and menopausal status. Our study was not powered to make meaningful analysis of these risk factors.

It is time to start fine-tuning our technique of surgical procedures like the uterosacral ligament that have been performed for decades. A randomized controlled trial that compares surgical techniques, suture type, and outcomes can greatly contribute to guiding surgeon practice. However, until such research is done, our study suggests that permanent braided suture should not be the first line material used in vaginal surgeries such as the uterosacral ligament suspension.

Acknowledgments There are no acknowledgments.

\section{Conflicts of interest None.}

Open Access This article is distributed under the terms of the Creative Commons Attribution Noncommercial License which permits any noncommercial use, distribution, and reproduction in any medium, provided the original author(s) and source are credited.

\section{References}

1. Bump RC, Mattiasson A, Bø K, Brubaker LP, DeLancey JO, Klarskov P et al (1996) The standardization of terminology of female pelvic organ prolapse and pelvic floor dysfunction. Am J Obstet Gynecol 175:10-17

2. Toglia MR, Fagan MJ (2008) Suture erosion rates and long-term surgical outcomes in patients undergoing sacrospinous ligament suspension with braided polyester suture. Am J Obstet Gynecol 198:600.e1-600.e4

3. Luck AM, Galvin SL, Theofrastous JP (2005) Suture erosion and wound dehiscence with permanent versus absorbable suture in reconstructive posterior vaginal surgery. Am J Obstet Gynecol 192:1626-1629

4. Jenkins VR II (1997) Uterosacral ligament fixation for vaginal vault suspension in uterine and vaginal vault prolapse. Am J Obstet Gynecol 177:1337-1344

5. Karram M, Goldwasser S, Kleeman S, Steele A, Vassallo B, Walsh P (2001) High uterosacral vaginal vault suspension with fascial reconstruction for vaginal repair of enterocele and vaginal vault prolapse. Am J Obstet Gynecol 185:1339-1343

6. Barber MD, Viso AG, Weidner AC, Amundsen CL, Bump RC (2000) Bilateral uterosacral ligament vaginal vault suspension with site-specific endopelvic fascia defect repair for treatment of pelvic organ prolapse. Am J Obstet Gynecol 183:1402-1410

7. Amundsen CL, Flynn BJ, Webster GD (2003) Anatomic correction of vaginal vault prolapse by uterosacral ligament fixation in women who also require a pubovaginal sling. J Urol 169:17701774

8. Silva WA, Pauls RN, Segal JL, Rooney CM, Kleeman SD, Karram MM (2006) Uterosacral ligament vault suspension: fiveyear outcomes. Obstet Gynecol 108:255-263

9. Wheeler TL 2nd, Gerten KA, Richter HE, Duke AG, Varner RE (2007) Outcomes of vaginal vault prolapse repair with high uterosacral suspension procedure utilizing single sutures. Int Urogynecol J Pelvic Floor Dysfunct 18:1207-1213

10. Schull BL, Bachofen C, Coates KW, Kuehl TJ (2000) A transvaginal approach to repair of apical and other associated sites of pelvic organ prolapse with uterosacral ligaments. Am J Obstet Gyneol 183:1365-1374

11. Aronson MP, Aronson PK, Howard AE, Morse AN, Baker SP, Young SB (2005) Low risk of ureteral obstruction with "deep" (dorsal/posterior) uterosacral ligament suture placement for transvaginal apical suspension. Am J Obstet Gynecol 192:1530-1536

12. Cruikshank SH, Muniz M (2003) Outcomes study: A comparison of cure rates in 695 patients undergoing sacrospinous ligament fixation alone and with other site-specific procedures - a 16-year study. Am J Obstet Gynecol 188:1509-1512 